\title{
PAKISTAN AFGHAN RELATION: HISTORY CONFLICTS AND CHALLENGES
}

\author{
Dr. Muhammad Ali \\ Associate Professor \\ Department of Political Science \\ University of Karachi \\ muhammad.ali@uok.edu.pk \\ Malik Safdar \\ Ph.D Scholar \\ Department of Political Science \\ University of Karachi \\ malik.safdar@live.com
}

\begin{abstract}
Pakistan and Afghanistan, two immediate Muslim neighbors, that not only share a common border but also have many other commonalities such as; linguistic, strong historical, ethnic, cultural, and religious ties. Despite of its geo-strategic location and various common factors, nature of Pak-Afghan ties the nature of PakAfghan relations is characterized by mistrust and suspicions and painful experience for both of them. Since its inception, Pakistan faces a hostile attitude from its western neighbor Afghanistan. Except during the Taliban's four-year era, all the rulers of Afghanistan showed fluctuating degrees of dissatisfaction towards Pakistan. Conflict over Duran line, Soviet-Afghan war Pakistan support to Taliban, Pakistan role in War on Terror, and growing cross border militancy has stained relation between both countries. The main objective of this study is to evaluate the Pakistan Afghanistan relation in a historical context and highlight those factors which were the main hurdles in the way of a smooth and positive relation. The study also identifies the challenges, envisages
\end{abstract}


the prospects, and proposes ways for narrowing the gap between the existing and desired format of relationship.

Keeping view of the objective, study is dived into three parts. Part one deals with research problems in a historical context. The second part evaluates those factors which are responsible main obstacles in the way of a positive relationship between both Islamic countries. Conclusion and recommendation would be discussed in the last section of the study. Paper concludes that there would be no durable relation that can be improved or normalized unless the lack of confidence and mistrust that characterize their relations is addressed. It is needed to take an effective mechanism from both sides which generate an environment that is favorable to longlasting peace and security in the region.

Key Words: Afghanistan, Pakistan, Duran line, Peace Process and Post 9/11

\section{Introduction}

Interstate behaviour can exhibit three types of group relations, namely, conflict, competition, and cooperation While the majority of situations reflect 'cooperation and competition (Ali Meherunisa2001:143) . it is unfortunate that Pakistan-Afghanistan relations have led to a steady undertone of conflict, competition rather than cooperation and cordiality. Pakistan and Afghanistan, - two Muslim immediate neighbors, sharing 2640 kilometers land border which is frequently known as Durand Line. This line is since centuries, crossed each day by thousands of people, which is a handy source of people-to-people contacts as well as trade and economic interactions. Afghanistan, a landlocked country that acts as a bridge between South Asia and the Middle East, due to its geostrategic signification and location, Afghanistan is a gateway to natural resources-rich Central Asian state, it offers one of the shortest and most cost reduction effective air and land routes for access to natural resources-rich Central Asian States to other regions and global. Afghanistan is also important for it lies adjacent to the Middle East and Central Asian countries 
who have got more than half of the world's total oil reserves iThe country shares its border with Iran and Turkmenistan, the countries who are the world's second and third largest producers of natural gas. The pipeline routes for the transference of gas is one of its kind of important economic rivalry especially in this area where two of the world's largest gas reserves are present. . (Kahn \& Than .K 2015) Afghanistan, in this battle for geopolitical battle, is a strategic piece of real state.

\section{Comparison Pakistan And Afghanistan At A Glance}

\begin{tabular}{|c|c|c|}
\hline Official Name & Islamic Republic of Pakistan & Islamic Republic of Afghanistan \\
\hline Area (sq km) & $796095 \mathrm{~km}$ & $652,864 \mathrm{~km}$ \\
\hline Bordered by & $\begin{array}{l}\text { India Afghanistan Iran } \\
\text { And China }\end{array}$ & $\begin{array}{l}\text { Turkmenistan, Uzbekistan, } \\
\text { Tajikistan } \\
\text { Pakistan, Iran and China }\end{array}$ \\
\hline Population & $212,228,286(\underline{5 t h})$ & $32,225,560(\underline{44 \mathrm{th}})$ \\
\hline Density per $\mathrm{Sq} \mathrm{Km}$ at 2019 & $245.4 /(56$ th $)$ & $46 / \mathrm{km}^{2}(119.1 / \mathrm{sq} \mathrm{mi})(174 \mathrm{th}$ \\
\hline Capital & Islamabad & Kabul \\
\hline Language & $\begin{array}{l}\text { Urdu and English are official } \\
\text { language } \\
\text { Punjabi }(39 \%) \cdot \text { Pashto }(18 \%) \\
\text { Sindhi }(15 \%) \cdot \text { Balochi }(3 \%)\end{array}$ & $\begin{array}{l}\text { Pashto } 16.8 \text { million (48\%) } \\
\text { Persian, Dari }\end{array}$ \\
\hline Religion & $\begin{array}{l}\text { Muslim About } 96 \text { percent } \\
\text { Islam is official Religion }\end{array}$ & $99.7 \%$ Islam (official) \\
\hline Government & $\begin{array}{l}\text { Islamic Republic, Federal } \\
\text { Parliamentary }\end{array}$ & $\begin{array}{l}\text { Islamic Republic, Unitary } \\
\text { Presidential }\end{array}$ \\
\hline Head of State / Government & $\begin{array}{l}\text { Prime Minster } \\
\text { Mr. Imran Khan since }\end{array}$ & $\begin{array}{cl}\text { President } & \text { Muhammad Ashraf } \\
\text { Ghani since } & \text { 29 September } 2014 \\
\end{array}$ \\
\hline Economy $\underline{\text { GDP }}(\underline{\mathrm{PPP}})$ & 1.254 trillion $(\underline{23 \mathrm{rd}})$ & 72.911 billion $(\underline{96 \text { th }})$ \\
\hline Per capita & $1,388(\underline{151 \mathrm{st}})$ & $2,024(\underline{169 t h)}$ \\
\hline HDI & 0.557 medium $\cdot \underline{154 \text { th }}$ & 0.5111 ow $\cdot 169$ th \\
\hline Regional membership & $\begin{array}{l}\text { UNO, NAM ECO, SAARC, } \\
\text { OIC }\end{array}$ & UNO, NAM ECO, SAARC, OIC \\
\hline
\end{tabular}




\section{Source Europa World Year Book 2019}

Both neighboring countries not only share a common border but also have many other commonalities such as; linguistic, socio-economic, and strong historical, ethnic, cultural, and religious ties. Both countries are common members of various regional and sub-regional organizations like the Economic Cooperation Organization (ECO) South Asian Association for Regional Cooperation (SAARC) and the Organization Islamic Conference (OIC). Despite its geostrategic location and bonds of faith, history, and culture, Pakistan ties with Afghanistan remain a painful experience rather than smooth and relation like other countries. since from its inception Pakistan face hostile attitude from its western neighbor Afghanistan. Except during the Taliban's four years era (1997-2001) all the ruler of Afghanistan have shown fluctuating degrees of dissatisfaction towards Pakistan conflict over the Durand line, soviet Afghan war Pakistan support to Taliban, Pakistan's role in War on Terror, and growing cross border militancy has stained relation between both countries. Post $9 / 11$ bilateral relations have been revolving around serious distrust, blame game, refugee crisis, cross border violation leading to an environment of low-intensity hostility towards each other. Keeping view of the above introduction bilateral relation between both countries can be divided into three section / phases, which would help to understand the bilateral ties in the present scenario at regional and global context:

- Pakistan Afghanistan Relations: 1947- 1979

- Pakistan-Afghanistan Relations since 9/11

- Future challenges

\section{Pakistan Afghanistan Relations: 1947- 1979}

From the very day of its inception, Pakistan demonstrated deeply positive sentiments towards the Muslim world based on common bonds of faith, culture, and history, and attached great importance to its relations with the Muslim states. Afghanistan, though a Muslim country, created the problem of Pakhtunistan for 
Pakistan, besides making territorial claims on Pakistani territory in the provinces of the NWFP and Baluchistan. It gave financial aid to the Pakistani tribal and encouraged them to challenge Pakistani authorities. Afghanistan was the only country to vote against Pakistan's admission to the United Nations in 1947. It is a written fact in the history that Afghanistan was used as the buffer zone against the huge white beer in South Asia by the British government, nevertheless, despite this cruel reality, the monarchial government had been found at ease in Afghanistan and British colonial master. (Javaid, U. 2016:137). All this is highly correlated with the historical Franco-Afghan wars in the $19^{\text {th }}$ and $20^{\text {th }}$ centuries in which the ill-will against Pakistan was deeply rooted where British powers were taking control over the topographical area of Pakistan when Pakistan did not even emerge on the global map.

As it has been discussed earlier that maintaining friendly relations with all neighboring states in general and Muslim states particulars is a basic principle of Pakistan's foreign policy. But Afghanistan has been a problem for Pakistan since 1947. The core issue has been Afghanistan's refusal to recognize the Durand line drawn by the British in 1893 as the official border between the two countries and, by extension, claims to the NWFP and the Pathan-dominated parts of Baluchistan. Afghanistan's support for agitation among some Pathans in the NWFP for an independent. homeland, 'Pakhtoonistan' or 'Pashtunistan', strained relations with successive governments in Pakistan during the 1950s and 1960s. Afghanistan disrespecting this intention of Pakistan had a very rude awakening on the day when Pakistan had to be accepted as an independent state. Afghanistan not only refused to accept Pakistan's independence but also voted against it in the United Nations. (Durani, M. U., \& Khan, A. 2009). It claimed the ownership over the whole NWFP, Baluchistan, and some areas of Punjab and also questioned the agreement about Durand Line that was signed in order to formalize Afghanistan's Frontier with the British-ruled Hindustan. Importantly, Kabul declared the Durand Line to be the imaginary line on July 26, 1949, voiding all the agreements that were approved previously. )Shah, S. 2017). But these claims went unnoticed at that time as the world had moved on from the same old-fashioned $18^{\text {th }}$-century geopolitics. (Ahmad, N. 2016, ) 


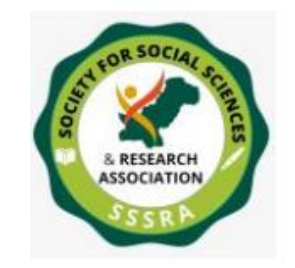

Pakistan Afghan Relation History Conflicts......

Although the negative vote was withdrawn soon after, it sowed the seed of mistrust in the earlier days of evolution of bilateral relations leaving a lasting bad taste. (Shamshad A 2010 :303), The border arrangement and already existing Durand Line was the first issue to be raised by Afghanistan on different forums, despite the fact that the Border Agreement of 1893 was continuously ratified by the successive rulers of Afghanistan. As per the treaty, Durand Line has the status of the international border and according to Article 11 of Vienna Convention on Succession of States in Respect of Treaties (VCSSRT), it has international acceptance and legitimacy. (Ahmad Shayeq Qassem, 2008 :13) That's why, though Afghanistan has raised the Durand Line issue at bilateral level as an occasional pressure point against Pakistan, it has never taken it up at any multilateral forums. Based on Durand Line, Afghanistan often puts forward its territorial claims over Pakistani territories covering some of the Pashtun inhibited areas falling in tribal areas, Khyber Pakhtunkhwa, and parts of Balochistan province.It was right after the inception of the country that bilateral relations between the two became ill-fate particularly from 1947 to 1963. Despite being neighboring countries and close ethnic ties, discord and conflict became the basis for the relations. The era of Sardar Doud with two spells (from 1947 to 1963 and again 1973 to 1978) shows the most disturbed period and painful experience in terms of the relationship between both countries. Sardar Doud's era was responsible for various unpleasant incidents such as border security clashes, disruptions embassies, the embargo of trade, burning of national embassies and flags, etc are the proof of bitter bilateral diplomatic ties. .( (Durani, M. U., \& Khan, A. 2009).

To take the advantage of the initial domestic and international problem faced by Pakistan after independence, Afghanistan has launched two-fold strategy to weaken and destabilizes Pakistan. Firstly, it has openly joined Pakistan's rival India and also the Soviet Union. Secondly, it provided politically and financially assistant and backed secessionist politicians in NWFP to weaken Pakistan. All these acts are warmly welcomed and fully supported by India. Due to Indo-Afghan Nexus, Pakistan's joined SEATO and CENTO for defense purposes, this act makes more irritation between two Muslim countries. When Pakistan joined the defense pacts in 1954 and 1955, Afghanistan exploited the occasion to provoke feelings of 


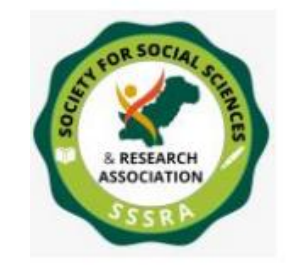

Pakistan Afghan Relation History Conflicts......

indignation in the Middle East. .In these anti-Pakistan activities, the Afghan authorities were supported by India whose interest lay in ensuring that in the event of war with Pakistan over Kashmir, the Afghans should open a second front against Pakistan in the North-West Frontier.' (UK.Diss 2019) Despite this, Pakistan followed a policy of patience with Afghanistan and gave the facilities for trade and passage of goods by its railway to Afghanistan.

\section{Detent in Pak- Afghanistan Relations (1963-73)}

on a number of occasions, Iran's mediation helped ease out the tense relations of Pakistan with other countries. In intra-regional disputes especially, Pakistan found in Iran as a steadfast friend. In 1963, Iran's -mediation helped restore diplomatic ties between Pakistan and Afghanistan after a break of two years. King Zahir Shah of Afghanistan was coaxed to tone down his support for the 'Pakhtunistan' issue. (Ali Meherunisa,:145) After the successful mediation of Iran (Tehran Accord) Pakistan and Afghanistan settled to reinstate their diplomatic ties, resume commercial and trade relations and open their air and land border. it was further decided by both countries that they resolve all their mutual disputes according to international law and develop an atmosphere of mutual trust and friendship. All these confidence-building measurements (CBMs) dilute the focus of Kabul on the long-standing issue of Pakhtunistan and made positive views towards Pakistan by Afghan rulers. During the state visit of King Zahir Shah to Pakistan in 1968, further increase of mutual relation and increase of economic cooperation and trade. Moreover, the decision to disband one unit by Islamabad was also welcome by Kabul which further increased the positiveness of Pak-Afghan relations including upsurge mutual respect and economic cooperation. Notwithstanding this bitterness, during two India Pakistan wars (1965 \& 1971), Afghanistan upheld firm impartiality and assured Pakistan of posing no threat from its western border which helped Pakistan in relocating its troops from the Pak-Afghan border to combat zones on the India-Pakistan border. (Umar S,2009) Throughout these years Afghanistan remained under the rule of King Zahir Shah. It was the time when the relationships between both Islamic countries were going about enough matured to resolve all their disputes and historical legacy of mistrust. Hardly had bilateral 
relations between the two were becoming trustful when they were obstructed by a sudden change in Kabul's corridors of power. In 1973, Lt-Gen. Mohammad Daoud Khan once again gains power after overthrew the Zahir Shah, who was on a visit to Europe. With the passage of time, during the Sardar Daud era in the 1970s, Kabul once again raised the issue of Durand Line through a dubious radio station "Azadi Radio". (UK.Diss 2019) It also made effort to move Afghan troops to the border areas. These belligerent actions made the relations between the two countries so tense that Sardar Daud refused of participating in the Islamic Conference Summit 1974, which was held in Lahore. Doud's leadership style quickly alienated the Afghan people, particularly the leftwing faction which join together to oust him from power in 1978. After Daud's era, all rulers of Afghanistan were propelled to power by covert or overt Soviet support, until the Soviets invaded Afghanistan militarily in 1979. Following the April 1978 coup in Afghanistan, the communist regime of Nur Mohammad Taraki revived the 'Pakhtoonistan' question, and the internal revolt in Afghanistan inaugurated a stream of refugees into the NWFP and Baluchistan that was to have grave implications for the internal stability of both countries for several decades. Communist rule rapidly led to factional infighting which prompted the USSR to invade Afghanistan in December 1979. (Mehmood S2000 :286)

\section{Pak Afghan Relation After Soviet Invasion (1979 - 1996)}

It was on December 27, 1979, when the Soviet invasion of Afghanistan. As a result, the invasion was perceived by Islamabad as a calculated move. Moscow's takeover of Afghanistan deeply perturbed Zia ul Haq's sense of Islamic brotherhood In the opinion (Ahmad S Q, 2008 : 13) Pakistan, right after the invasion, seemed to have pursued several goals in the Afghan conflict including getting closer in a tie with Mujahideen in the war against the Soviets, convincing the Pushtoons on the other side of the border to come closer to Islamabad so that it may influence them to withdraw with their principle separatist claim, flair up the anti-Indian sentiment, increasing the fighting capability to the extent of becoming a nuclear power, etc. Soon after the Soviet military intervention in Afghanistan, Pakistan tried to explore the prospects of a negotiated settlement of the problem based on the withdrawal of 
Pakistan Afghan Relation History Conflicts......

the Soviet troops, the guarantee of non-intervention, and the return of the Afghan refugees. Pakistan's efforts enjoyed international support including that of the US, China, and the Muslim world. Pakistan took the initiative of organizing the meeting of the foreign ministers of the Islamic countries at a conference, which condemned the Soviet action, appointed a committee comprising foreign ministers of Pakistan and Iran, and secretary-general of the organization to resolve the issue. The committee could not make any headway because of the non-co-operation of the Soviet Union. The Afghanistan problem was also taken up by the UN General Assembly in January and September 1980, which passed resolutions with an overwhelming majority, calling for a peaceful settlement of the Afghanistan crisis, including the withdrawal of the Soviet troops.

\section{Pak-Afghan Relations And Geneva Accords}

The major accomplishment of Pakistan concerning the foreign policy front during this specific period was the signing of a historic Geneva Accord in April 1988, which formed the basis for an end of the Soviet occupation of Afghanistan. (Jilani Anees ,2001: 374) The accord was generously welcomed almost all over the world particularly involved parties in the Afghan conflict. It was due to the fact that after Vietnam (1964-1975), this was the first time that a super-power decided to withdraw from the on-going war to which it was deeply committed. (Europa World Year Book 2016:273)

During this period and until the pull-out of Russian troops (1989), the bilateral relations rode two divergent tracks - government to government hostile stream and people to people stream of empathy, warmth, and goodwill. Pakistan's government and public stood shoulder to shoulder with the people of Afghanistan in opposing and resisting the Soviet invasion and prolonged occupation, both diplomatically and militarily. For this reason, during this era, different regimes in Kabul, supported and mentored by the former USSR, remained at loggerheads with Islamabad. After the Geneva accords in 1988, Pakistan helped cobble together a broad-based government comprising of Mujahedeen leadership which had militarily resisted the Soviet occupation. After the Soviet withdrawal in 1988, The communist regime of 


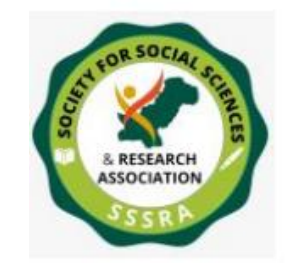

Pakistan Afghan Relation History Conflicts......

Najibullah stood no chance against the mujahidin forces and collapsed within a short span of time. The winning mujahideen formed a government in April 1992 by an agreement signed in Peshawar (Known as Peshawar Accords). This peace and power-sharing accord establish a post-communist Islamic State of Afghanistan. This agreement did not bring any durable peace in Afghanistan. With the fall of communism in Afghanistan, serious fighting broke out among the various ethnic factions within the victorious mujahidin. The Pashtun tribes, who collectively form Afghanistan's largest ethnic group and comprise approximately $40 \%$ of the total population, wanted to reassert their historic dominance over other ethnic groups by making an exclusive claim to power. The smaller ethnic minorities, notably the Tajiks and the Uzbeks, were resentful of the historic Pashtun domination in the country and saw an ideal opportunity to reverse that trend. The Tajiks and the Uzbeks, therefore, formed the Northern Alliance to oppose the various Pashtun warlords hankering for power. The civil war that ensued lasted for almost five years. It is against this backdrop that the Taliban came to power in Kabul in 1996. ( South Asia 2018:7)

The Taliban captured Kabul in September 1996, and fierce fighting subsequently erupted in the Panjshir Valley in the north of the country, where the Northern Alliance forces under the Tajik warlord Ahmed Shah Masoud had retreated. In western Afghanistan the forces of the Uzbek warlord Gen. Abdul Rashid Dostum also clashed with the advancing Taliban troops. By the late 1990s, the Taliban had taken control of most of the country (except for pockets of resistance in the north and the west) and declare its sovereignty by establishing an Islamic Emirate of Afghanistan by the massive diplomatic military and financial assistant provided by Pakistan. During the mid-1990s, when the Taliban launched its military campaign and attempted to through Afghanistan, it welcomed the active support of Arab and other foreign volunteers, as well as the help that it received from the Pakistani and Saudi intelligence communities. It was this first time in the history of Pak Afghanistan relations when Islamabad got a warm welcome from Kabul. Pakistan was at a much higher superiority than India. However, Pakistan's relation was a decline due to the Taliban's refusal to legitimate the long-standing issue of the Durand Line. It was a big setback for Pakistan. However, overall Pakistan's 
Pakistan Afghan Relation History Conflicts......

relations with all post-Soviet governments in Afghanistan remained very warm till $9 / 11$.

\section{Pakistan-Afghanistan Relations Since 9/11}

The terrible events of 11 September 2001 redefined Pakistan's relations with Taliban Afghanistan. The US attack on the Taliban regime allowed Musharraf to revive his weakening relationship with America and, once more, Pakistan assumed the mantle of a front-line state. Since then, although India has become the centerpiece of US strategy in South Asia, Pakistan has been able to exert some leverage on the USA, given its strategic geopolitical situation and importance in the continuing war on Taliban. It is important to mention here that Following the terrorist attacks on the USA in September 2001, the Indian Government communicated to the USA that it was willing to extend support to the US effort in Afghanistan. Despite India's enthusiasm, America did not give any importance to the Indian offer. Due to the geo-strategic location of Pakistan, which shares a long border with southern and eastern Afghanistan, the US cannot ignore the fact that Pakistan is a more important strategic actor with regards to military operations in Afghanistan than India. In December 2001 the Bonn Agreement was signed, under which the various ethnic groups of Afghanistan agreed to form a multi-ethnic interim government. In April 2002 an emergency Loya Jirga (Grand National Council) was convened in order to allow tribal leaders from various parts of the country to endorse the format of the new Government, which was headed by Hamid Karzai, a Pashtun leader supported by the USA, as President. However, Pashtun opinion regarding Karzai remained divided, with many regarding him with suspicion and mistrust. The formation of the interim government did not solve Afghanistan's security predicament. The country was divided into various enclaves that were controlled by different ethnic and tribal warlords. Hence, the writ of Karzai's Government did not extend much beyond the immediate surroundings of Kabul. (Europa World Year Book 2016:273) Hamid Karzai's administration remained in power till 2014 through the two elections. 
Pakistan Afghan Relation History Conflicts......

Despite occasional cordial overtures from both sides, Afghanistan's relations with Pakistan became increasingly strained during the presidency of Hamid Karzai. Ground tensions on the Durand Line arose following efforts by Pakistan to build outposts and secure the border. After showing initial warmth towards Pakistan, Hamid Karzai set out to build a more robust strategic partnership with India. India seized the opportunity and pampered in proxies by using Afghan territory as a springboard for launching terrorist operatives in Pakistan and for limiting Pakistan's access into Central Asia, hence marginalizing Pakistan's influence in the region. Indo-Afghan nexus also resurrected the issue of Durand Line through the formation of direct contacts with Pashtun political and tribal leaders within Pakistan. (Mairaj-ul-Hamid 2017: 59)

By 2005-06 relations between Kabul and Islamabad had become increasingly strained. Kabul remained accused that Pakistan harbored Taliban and during US President George W. Bush's visit to Pakistan in March 2006 the Afghan President joined senior US officials in Kabul in accusing Pakistan of allowing the al-Qaida leadership and operatives to hide in Pakistani border areas, drawing a furious. In August 2013 Karzai met the new Pakistani Prime Minister Nawaz Sharif in Islamabad and declared that Pakistan's role in any long-term Afghan peace settlement remained crucial. Nawaz Sharif made a reciprocal visit to Kabul in November, during which he assured Karzai of Pakistan's willingness to assist the Afghan peace process. However, a significant improvement in Afghan-Pakistani relations was evident following the presidential inauguration of Ashraf Ghani in September 2014. Ghani visited Pakistan twice in the ensuing months and, most importantly, visited key Pakistani security and economic partners such as China and Saudi Arabia, trying to convince them that instability in Afghanistan would not be in their interest, particularly after the departure of Western military forces. He stressed that "the hostility between Pakistan and Afghanistan has been buried in the past two days Ghani also appeared to be willing significantly to downsize diplomatic relations and security co-operation with India, an old Pakistani demand, in exchange for greater Pakistani co-operation in bringing Afghan insurgents to the negotiating table. But a few months later he also opted for one of his predecessorsHamid Karzai. After a couple of attacks presumably by the Taliban on Kabul 
Airport and the Afghan Parliament, Ashraf Ghani alleged Pakistan for steering the attacks and renounced: Clashes between troops from the two countries at the Torkham border crossing in June 2016 appeared to discourage any likelihood of Afghan Pakistani co-operation on security issues in at least the short term. AfghanPakistani relations remained tense at mid-2017, with more border closures and mutual accusations of support for insurgent groups. ( South Asia 2018:7)

\section{Issues And Challenges}

Bilateral relationships are always carried out with a package of challenges and opportunities. Indeed there are greater where many regional and international players are involved to end this long-simmering conflict. Nevertheless, the leadership of the two countries now requires to stand-up to the occasion and capitalizes on opportunities. If the relationship continues to remain hell-bent in the context of irritants, only third parties that are unwilling to bring peace to the region would benefit at the cost of the wellbeing of the people of two countries. Around one million Afghans have so far been killed in foreign military interventions, both of which were led by the Soviet Union between 1979 and 1989 as well as the USled coalition forces from October 2001 to date. They have remained homeless and ended up as being refugees in Pakistan, Iran, and other neighboring countries. As many as three generations of Afghans have been affected by civil war and still, there is no letup as far as violence is concerned. Until and unless the country does not become stable, it will continue to destabilize its neighbors especially Pakistan. As far as the US is concerned, it spent as many as \$1 trillion in Afghanistan in its longest war in history. It has almost withdrawn without accomplishing regrettably any desired results. (Ahmer Monis 2020)

By default, Pakistan has a key role in Afghan reconciliation processes, both ongoing as well as those which could evolve. Pakistan has always supported the "Afghan-led and Afghan-owned," peace process. However, there are serious limitations with regards to this concept. Besides the peace process, there are many areas where Pakistan and Afghanistan could work jointly. They could, for example, put in combined effort to improve the life standards including health and education 


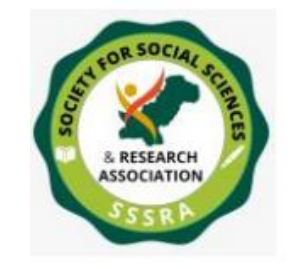

Pakistan Afghan Relation History Conflicts......

facilities of their citizens and increase employment opportunities through increased bilateral trade. Both countries need each other: Pakistan needs Afghanistan for stability, economic prosperity, and for the security of its borders; and notwithstanding Afghan leadership's desire to diversify the country's trade through Iranian Chabahar port, Afghanistan will continue to need Pakistan for Karachi and Gwadar ports, as well as Pakistani land routes to trade with other countries. Afghanistan and Pakistan need to adopt a more realistic approach towards each other's sensitivities. India's factor in the respective policies of both sides has remained a factor of deterioration in the relations. Although, as an independent and sovereign state, Afghanistan has the liberty to choose friends of its interactions with such friends should not pose security threats to the neighboring countries. The presence of India's consulates in Afghanistan's major cities and their role in jeopardizing the Western border is a matter of concern for Pakistan.

Bilateral ties can also be strengthened if both Kabul and Islamabad opt for economic cooperation and trade as the basic foundation for their engagement. Being a landlocked state, Afghanistan's trade has been passing through Pakistan. Afghanistan is the second-largest export market of Pakistani products and both are the largest trading partners. Though bilateral official trade level is very low, i.e. $\$ 1.5$ billion,59 informal trade and smuggling of various goods accounts for over $\$ 6$ billion.60This informal trade, though to the peril of both economies, is one of the underlying strengths of people to people bondage. Improvement in road infrastructure and removing institutional constraints for making the travel between the two countries easy could further strengthen people to people relations. (Mairajul-Hamid 2017 : 59) They already have the Afghanistan Pakistan Transit Trade Agreement (APTTA) in place, as a rational and viable source to strengthen the bilateral economic ties and trade with other regional states. Diplomatic initiatives are required to stress upon Afghanistan to consider delinking Pakistan's trade with Central Asia with allowing a free two-way Afghan ride to India or with providing India access to Afghanistan and beyond through its land routes as one of the CBM. India is already trading with Afghanistan and beyond, through Karachi port. Otherwise, Pakistan may link its trade with Central Asia with Afghanistan's usage of Pakistani ports like Gwadar and Afghan participation in China Pakistan 


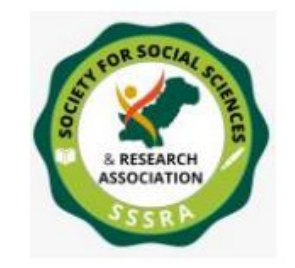

Pakistan Afghan Relation History Conflicts......

Economic Corridor (CPEC). Kabul needs to realize that CPEC enables Pakistan to trade with Central Asia and beyond while bypassing Afghanistan. Moreover, there is a serious need for a mutually agreed roadmap to formalize the informal component of bilateral trade; as and when official trade jumps to five-fold, it would strengthen state to state relations. (Mairaj-ul-Hamid : 61)

\section{Conclusion}

Being an immediate neighbor, Pakistan always gives dominant Significant to its relations with Afghanistan as Pakistan's peace and stability depend on Afghan peace and stability. Pakistan from the first day of its inception has been in mere support of clenching friendly relationships with the other Muslim countries as an important notion of its foreign policy. However, Afghanistan nurtured the negative attitude in the face of their shared colonial legacy. Traditionally, the Pak-Afghan relationship has been characterized by mutual mistrust and lack of confidence and third parties have always been a decisive factor in determining the Pak-Afghan relations. Keeping in view the above comprehensive analysis concerning PakAfghan fluctuating bilateral relations, Pakistan from the day of its independence has been in mere support of clinching amicable relations with Afghanistan and other Muslim countries as an important paradigm of its foreign policy. However, Afghanistan kept on nurturing a negative attitude in the face of their shared colonial legacy. Based on the above-mentioned geostrategic importance of both neighboring states, it is certain that both must remain engaged in their respective identities and roles in the region. Therefore, the solution of the border issues that have been prolonged between Pakistan and Afghanistan should settle down on a prompt basis provided the fact that the political interests of both the countries must not be compromised. There is a major overlap area of national interests of the two countries, with exception of a few complexities. It must not be understood by both the countries that commonality of interests is driven by geographical connectedness, cultural and ethnic and historical similarities. Both countries have to safeguard their interests by engaging with each other with the cooperation they should work in unison to overcome irritants. Working out robust and durable peace with a countrywide insurgency led by the Taliban is the need of the hour. The 
differences within the Kabul government circles for major appointments and negotiations with the Taliban and other militants are obstructing the bringing of long-term stability.

Afghanistan cannot achieve durable peace all alone, co-opting Pakistan would help to achieve it together. The Afghan government has to cede political concessions first to bring the Taliban to the negotiation table; and then for keeping them, engaged till final settlement. The rise of Daesh (ISIS) and its spread in Afghanistan is another area warranting close coordination between Afghanistan and Pakistan. Pakistan should be generous in letting Afghan refugees return at their own pace. Afghanistan should respect Pakistan's sensitivities concerning its security issues with India and avoid overt and covert appeasement of India at the cost of Pakistan. Islamabad should also realize this fact that no one is favorite for it in Kabul .Afghanistan needs to abide by its international obligations, firstly about the demarcation of the international border and secondly follow the international norms with regard to border management for putting an end to drugs, small arms, and human trafficking as well as cross border attacks. The international community and the neighboring states are obliged to respect the sovereignty of Afghanistan and help it out in its stabilization instead of preparing for another great game and use of Afghanistan as a battlefield of proxy wars against each other. Paper concludes that there would be no durable relation that can be improved or normalized unless the lack of confidence and mistrust that characterize their relations is addressed. It is needed to take an effective mechanism from both sides which generate an environment that is favorable to long-lasting peace and security in the region. 


\section{References}

Qassem, A. S., \& Durand, H. M. (2008). Pak-Afghan Relations: The Durand Line Issue. Policy Perspectives, 5(2). 87-102.

Ahmad, N. (2016, June 21). Analysis: The Grim Reality of Pak-Afghan. The Express Tribune: https://tribune.com.pk/story/1127035/analysis-grim-reality-pakafghan-relations/

Monis, A. (2020, November 27). Who will be the beneficiary of Afghan Peace? Express Tribune. https://tribune.com.pk/story/2273688/who-will-be-thebeneficiary-of-afghan-peace.

Meherunisa, A. (2001). Readings in Pakistan Foreign Policy 1971-1998. Oxford University Press .

Durani, M. U., \& Khan, A. (2002). Pakistan-Afghan Relations: Historic Mirror. The Dialogue, 4(1), 25-61.

Europa Publications (eds). (2016). Afghanistan. Europa World Year Book. 57 ed. vol 3. London: Routledge.

Javaid, P. (2020). Analyzing the Dynamics of Pakistan-Afghanistan Relations: Past and Present. South Asian Studies, 31(1).

Jillani, A. (2001). Pak-Afghan Relations, 1958-1988. In Readings in Pakistan Foreign Policy 1971-1998. Edited by Ali Meherunisa. Oxford University Press.

Kahn \& Than. K. (2015). Pipeline Politics: New Gas Route Revives Russian Rivalry with West. Reuters. https://www.reuters.com/article/us-russia-gas-europeidUSKBNOLS25620150224 Access on 22-12-2020

Hamid, M. Ul. (2017). Pak-Afghan Ties: Evolution, Challenges and the Way Forward. Policy Perspectives 14 (1), 59. 
Safdar, M. (2000). Pakistan Political root and development 1974-1999. Oxford University Press.

Shah, S. (2017, May 09). History, Controversies Linked to 114-year-old Durand Line Pact. The News International. https://www.thenews.com.pk/print/203283History-controversies-linked-to-114-year-old-Durand-Line-pact.

Ahmad, S. (2010). Pakistan and World Affairs. Lahore: Jahangir Books.

Europa Publications. (2017). South Asia. Europa Regional Survey of The World 2018. Vol.4 London: Routledge. 7-10.

All Answers Ltd. (November 2018). Afghanistan and Pakistan Relations After 9/11. https://ukdiss.com/examples/afghanistan-and-pakistan.php?vref=1.

Umar S, (2009). Pakistan's Foreign Policy toward Afghanistan from 19472008," http://en.afghanistan.ru/doc/130.html. 